\title{
Penta Helix Model In The Community Empowerment Around Coal Mine In Maburai Village Tabalong Regency
}

\author{
Muhammad Riduansyah Syafari \\ Departement of Public Administration \\ Lambung Mangkurat University \\ Banjarmasin, Indonesia \\ muhammad.syafari@ymail.com
}

\begin{abstract}
The Penta-Helix Model in community empowerment around coal mine is taken from the community empowerment program of PT Adaro Indonesia tbk and Partner, using corporate social responsibility fund. This model involves five components of stakeholders that are synergized, and illustrated in the practice of empowering housewives in the village of Maburai through handicrafts training and development programs of Sasirangan batik, with the pattern of Langsat fruit and torch fire, typical of Tabalong. Its mine stakeholders are Disperindagkop of Tabalong District, CSR of PT Adaro Indonesia tbk and Partner, related NGO, Craftsment community of Maburai'sSasirangan batik, and the Press. The results show that the synergy through the Penta Helix model can improve the empowerment of housewives as artisan community of Sasirangan batik with typical Tabalong patterns, and capable to encourage the birt of six artisan communities of Sasirangan batik in six other villages in Tabalong District with the mixed pattern between Tabalong and Dayak.
\end{abstract}

Keywords-Penta Helix Model, community empowerment, CSR Fund

\section{INTRODUCTION}

Community empowerment through the budget of corporate social responsibility toward the community around coal mine in the program of village development in Tabalong Regency has not been optimal. According to data from corporate social responsibility division, PT Adaro Indonesia and Partner 2016, there are 32 villages in the first area that receive the budget of corporate social responsibility. Yet, from those numbers, only three villages did the community empowerment program, while other villages were only at physical construction. The three villages were Maburai - Subdistrict of Murung Pundak, Pasar Panas Village - Subdistrict of Kelua, and Mantuil Village - subdistrict of MuaraHarus (Source: a report from CSR Division of PT Adaro Indonesia, 2015).

According to introductory study, community empowerment running well only occurred in Maburai Village toward housewives. There were many stakeholders involved, namely CSR of PT Adaro Indonesia and Partner, Government of Tabalong, DPC of HIPMIKINDO of Tabalong Regency, CSR committee of Bina Desa Maburai, housewives associated with Kerajinan Bunda Tanjung Bersinar group, and also from Mass Media (TV Tabalong). The difference between this research and other research lies in the object of empowerment, namely housewives.

According to reference [1] it shows the indication of the entry of Penta-helix approach in community empowerment. As with the research on reference [2] about Penta-Helix model. As for the concept of community empowerment, Novek in his research emphasizes the empowerment of leadership at the grassroots [3]. O'Connor emphasizes the need for revisioning family support groups [4]. Pigg emphasizes in his research about Three Faces of Empowerment: Expanding the Theory of Empowerment in Community Development [5]. The research which relates to the gender is conducted by Turner et al. discussing the issues about feminist and empowerment theory and social work practice [6]. The difference between this research and previous research is in its focus, namely community empowerment around coal mine toward housewives with the approach of Penta-Helix model. The source of the budget for the empowerment of housewives is from the corporate social responsibility funds of PT Adaro Indonesia and Partners.

The problem to be described in this study is "How is the Penta Helix Model in communities empowerment around coal mine for housewives in Maburai village, MurungPundakSubdistrict, Tabalong District. The benefit that will be obtained through this research is to find an effective community empowerment model in terms of the Penta-helix model approach.

\section{METHOD}

This study uses a qualitative, descriptive approach with primary and secondary data sources. The data collection techniques are observations, interviews, and documentations; moreover, a triangulation strategy is chosen for data validity. 


\section{RESULTS}

\section{A. Penta Helix Model in community empowerment around coal mine in Maburuai village}

Community empowerment toward housewives in Maburai village is a part of community empowerment around coal mine through CSR fund of PT Adaro Indonesia and Partner. There are many multi-stakeholders involved in the process of empowerment activity. The stakeholders can be classified into five main empowerment groups called community empowerment with Penta Helix approach. They are local government, private corporate, civil society group like Widyaswara LPMP Banjarbaru province, DPC HIPMIKKINDO, CSR committee, pioneer of Maburai village, a community of Kerajinan Kain Batik Sasirangan khas Tabalong, and mass media, Tabalong TV.

\section{- Tabalong Government}

According reference [7], the government must focus on its function as regulator, facilitator or catalyst for development, while the production of public service is given to the private or non-government organization. The same cited on reference [10] that the business field and society become the organizer of development programs.

Tabalong Regency releases a regulation in term of decree No. 188.45/471/2014 about the establishment of coordination team and synchronization CSR program in the area of Tabalong Regency. PT Adaro Indonesia and Partners is one of the biggest donators for CSR fund and one of them is Program Bina Desa (Village Development). The regulation is the reference for allocation of CSR fund by PT Adaro Indonesia and Partner. The decree of regent in the secretarial team both envolves some departments or government services and accommodate a local house of representative (DPRD) Tabolang regency. The event organizer is CSR of PT Adaro Indonesia and Partner, and the supervisor is from subdistrict

In its realization, coordination and synchronization to activity of community empowerment are not formed yet with BPMPD. This issue is revealed by the interview with the chief and stuff of BPMPD Tabalong as follow:"There has no coordination yet with BPMPD, we have not made it, now we directly coordinate with BAPPEDA as government organization coordinating and synchronizing all activities.

The information from the BPMPD is justified by the CSR of PT Adaro Indonesia and Partners. Based on the results of the interview with the following interviewees, To coordinate with the BPMPD, we have not done it yet, we are currently coordinating BAPPEDA as a government agency coordinating everything, and synchronizing activities entirely. Technically, in the field we immediately coordinate with the Village Government, which then helps to socialize the community empowerment program through CSR funds, and form and appoint Community Empowerment Executing Committees that are selected through village meetings by stipulating through Village Head Decrees (SK). The Executing Committee and beneficiary groups did not want to involve the elements of the District or District government in the use of CSR funds, he said fearing that it would become complicated, too much bureaucracy and difficult to withdraw or even use CSR funds. the use of CSR funds, which is $60 \%$ minimum for community economic empowerment and $40 \%$ maximum for building physical infrastructure, operations can be used a maximum of $10 \%$ for the Organizing Committee, with a fund

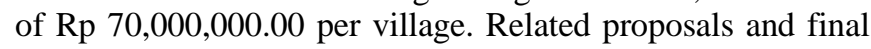
reports of activities must get approval from the District.

Based on the results of the interview above, technical coordination has not been realized with the relevant institutions, in this case the BPMPD. Likewise with the Subdistrict, so that the Subdistrict which endorses each final proposal and report on the use of CSR funds, just knows it and is not involved in directly supervising the community empowerment activities. Although coordination and synchronization of activities globally has been carried out with the BAPPEDA of Tabalong District, it is even carried out 3 or 4 times a year.

Facilitation of community empowerment activities is directly provided by the Village Government, and has not involved the BPMPD. The facilitation in question is to provide space for the implementation of village community empowerment activities through CSR funds. Facilitation by the Village Government in the form of holding a village meeting invites and selects the executive committee and the beneficiary group that will be determined based on the Decree of the Village Head. facilitating the proposal meeting and determining the economic activities to be empowered and disbursing and using CSR funds. The facilitation carried out by the Village Government has not yet reached the strategic and technical aspects of empowering beneficiary groups, the concept of science, training, Human Resources and infrastructure facilities are owned by BPMPD.

The function of the Regional Government in terms of regulation has been going well, but in terms of coordination it is still weak especially the coordination at the technical level for the implementation of community empowerment. This can be seen from the lack of coordination of delegation of authority from the Secretariat Team to the implementing technical agency, in this case the BPMPD.

\section{- Corporate Social Responsibility of PT Adaro Indonesia and Partners}

The private sector here is known as a development subject that participates in implementing sustainable development programs through community empowerment activities. PT Adaro Indonesia and Partners participate in the development of communities around coal mine through the support of village development programs. This program is a CSR program that emphasizes community empowerment programs around coal mine.

So, the existence of this CSR program is one of the important programs for sustainable development, not just charity purpose. The CSR of the Community Development Program in an empowerment format that has successfully become an embryo of UMKM is the empowerment of housewives in the village of Maburai, Murung Pudak District. The collaboration of various stakeholders related to the training in batik making in the village of Maburai grew and continued to develop into a community of craftsmen of Maburai's typical sasirangan batik, Tabalong with langsat fruit and torch patterns. We hope that this collaboration will continue, and the Support starting from the CSR of Bina Desa, colleagues from Pama Persada. We will continue with CSR support specifically for the development of the UMKM CSR of PT Adaro Indonesia ". 
The existence of private companies with CSR funds is important to be facilitated through local government regulations, so that it is beneficial for regional progress through CSR referring to sustainable development. Local governement regulation of Tabalong Regency related to the coordination and synchronization of development through the company's CSR funds in Tabalong District needs to be maintained.

\section{- DPC HIPMIKINDO and Intellectual Network}

The existence of socio-economic institutions such as HIPMIKINDO and the intellectual network of Widyaswara plays an important role in providing thought concepts, training and training activities to empower weak or powerless economic communities.

The existence of the Women's Empowerment Sector in DPC HIPMIKINDO, has a role to help empower housewives in Maburai village who are the beneficiary groups and are willing to be aware of themselves in participating in the training activities. Also concerned in helping women empowerment, such as housewives in Maburai village, they have enthusiasm and potential to help family finances, and are eager to participate in basic training in Sasirangan batik cloth, the number of participants is approximately 30 people, for basic training we have experts from widyasawara from Banjarbaru city our intellectual network and now we help develop into a community of Tabalong special sasirangan batik cloth craftsmen with langsat fruit and flame torch motifs, we through the Women's Empowerment Division of DPC HIPMIKINDO also fully support the empowerment of these housewives. The guidance and capacity building for mothers who are willing to continue basic training to advanced training is done through DPC HIPMIKINDO's HR who have attended advanced training and are already adept at making sasirangan batik cloth, our pattern is unique to Tabalong, so it has a unique appeal.

The coaching by DPC HIPMIKINDO and the training provided by Widyaswara for housewives, shows the important role of HIPMIKINDO and the intellectual network in empowering housewives. The output is in the form of housewives who have basic skills in making Sasirangan batik. The collection is in the form of developing basic abilities to advanced abilities and is skilled in making Tabirong-style Sasirangan Batik. The impact is in the form of a growing and developing community of craftsmen in the traditional batik motifs of Tabalong and giving encouragment to the potential for increased income and household welfare.

\section{- $\quad$ Pioneer Figures Community and Community}

Empowerment Housewives Tabalong Typical Sasirangan Batik Fabric Craftsmen.

The pioneering figure of community empowerment in Maburai village has a role in providing awareness raising, coaching and in building networking to various related stakeholders. Visits to various UMKM by selected housewives coordinated by pioneering figures have a positive impact on the empowerment of the housewives. The Executive Committee, the secretary is also a pioneer figure in the empowerment of the Maburai community, is a facilitator of community empowerment that is very active in guiding and fostering housewives in Maburai village.
The activeness of the pioneering figure was able to bring changes to housewives to become skilled craftsmen of Tabalong's typical Sasirangan Khas batik. They have brought the mothers before to the UMKM in Tabalong Regency, thank God they are enthusiastic, they offer training in making Sasirangan, they agree and are enthusiastic. For this reason, lobby DPC HIPMIKINDO, which has a field of women's empowerment, and thank God, they are also willing to assist in the formation and bring in experts from Banjarbaru widyaswara.

Now the housewives, initially only 10 people who were active and joined in the Bunda Tanjung Group shone, they continued to grow to 18 members. The target, executive Committee CSR of Maburai Village along with DPC HIPMIKINDO in the future is the realization of Tabalong's distinctive Sasirangan batik crafting community. Besides, it becomes a milestone to develop the Sasirangan batik crafters community in Maburai village to five other villages in Tabalong Regency.

The collaboration of pioneering figures and as secretary of the Executing Committee supported by the Village Head with DPC HIPMIKINDO Tabalong Regency, is able to realize the Tabalong typical sasirangan batik crafting community among the housewives of the Maburai village. The progress of the development also affects the presence of sasirangan batik craftsmen community in the other 5 villages in Tabalong Regency.

\section{- Press / Mass Media (Tabalong TV)}

The existence of electronic and mass media and even online media plays a role in publishing the results of UMKM crafts. UMKM Bunda Tanjung Bersinar as a UMKM Tabalong's new sasirangan batik craft that is just growing, certainly needs its product publication.

The media involved in the publication of the results of the Bunda Tanjung Bersinar UMKM product is local television, namely Tabalong TV. The range of Tabalong TV broadcasts is limited to Tabalong Regency, but the results of the broadcast are also published online. With online publication, anyone can access it, not only in Tabalong, but also nationally and internationally. They broadcast is evening or night with the reach of Tabalong Regency, there are online publications. Thus, the involvement of mass media, both electronic and press, has a significant role in helping the publication of the results of empowered UMKM products.

\section{CONCLUSION}

Empowerment of the community around the coal mine, particularly empowering housewives in the village of Maburai, is quite good, thanks to the realization of multi-stakeholder cooperation. Although, the role of facilitator from Tabalong District Government through the Community Empowerment and Village Government Agency has not been implemented. This weakness can be overcome by the activeness of the Implementing Secretariat as a pioneer figure in community empowerment in collaboration with DPC HIPMIKINDO Tabalong District for Women Empowerment, as well as other stakeholders in this regard CSR of PT Adaro Indonesia and Partners, Widyaswara training of Sasirangan Batik Fabrics, Community of housewives of craftsmen sasirangan batik 
ypical of Tabalong, Maburai Village Government, Disperindagkop Tabalong Regency, Tabalong TV and other related stakeholders. Community empowerment of housewives in Maburai village involves multi-stakeholders. Collaboration on community empowerment in the village of Maburai illustrates the phenomenon of the penta-helix approach involving 5 key stakeholders. Namely, the Tabalong District Government, CSR of PT Adaro Indonesia and Partners, DPC HIPMIKINDO Tabalong and the Widyaswaranya Network, Pioneer Leaders and the community of mothers who are stairs to the craftsmen of batik cloth, as well as the media (Tabalong TV).

\section{REFERENCES}

[1] Amrial and Emil Muhammad, Askar MA. 2017. Penta Helix Model: A Sustainable Development Solution Through The Industrial Sector. In HISAS Human and Social Science Journal ISSN : 2597-8640.
[2] Halibas, Alrence Santiago, Rowena Ocier Sibayan, Rolou Lyn Rodriguez Maata. 2017. The Penta Helix Model In Innovation In HAI Man: An HEI Perspektif. In Interdisciplinary Journal of Information, Knowledge, and Management, Volume 12.

[3] Novek, Eleanor M. 2009. Refraining a house of mirrors: Empowering Community in a Grassroots Leadership Program. In New Jersey Journal of Communication, Volume 7, 1999-Issue 1.

[4] O’Connor, Deborah L. 2008. Toward Empowerment: Revisioning Family Support Groups. In Journal Social Work With Groups, Volume 25, 2003-Issue 4.

[5] Pigg, Kennet E. 2009. Three Faces of Empowerment: Expanding the Theory of Empowermentin Community Development. In Community Development Society Journal, volume 33, 2002-Issue 1.

[6] Turner, G Sandra, et al. 2014. Feminist and Empowerment Theory and Social Work Practice. In Journal of Social Work Practice, Volume 29, 2015-Issue 2.

[7] Osborne, David and Ted Gaebler. (1999). MewirausahakanBirokrasi Reinventing Government MentransformasiSemangatWirausahaKeDalamSektorPublik(5th Printing; Abdul Rosyid, Trans). Jakarta: CV TerunaGrafika.

[8] Suhendra, K. (2006). Peranan Birokrasi Dalam Pemberdayaan Masyarakat. Bandung: Penerbit Alfabeta. 